\title{
IN VITRO PROPAGATION OF Balanites aegyptiaca (L) DEL., AN ENDANGERED MEDICINAL PLANT. \\ Mohamed A. ${ }^{1}$ and M.H. Bekhit ${ }^{2}$ \\ 1 Tissue Culture Unit, Desert Research Center, Ministry of Agriculture, Egypt. \\ 2 Plant Biotechnology Dept., Genetic Engineering \& Biotechnology Research Institute (GEBRI), Minufiya University, Sadat City, Egypt.
}

\section{ABSTRACT}

Young vigorous shoot tips of wild Balanites aegyptiaca (L) Del. were collected from Paris Oasis, Alwadi Algadeed, Egypt and used as the source of explants for micro-propagation. Shoots were established on MS basal solid medium supplemented with 6-benzyladenine (BA) at different levels combined with anaphthalene acetic acid (NAA). MS medium without any growth regulators enhanced shoot elongation, while shoots response and axillary branching were affected by BA levels. Shoots productivity were significantly affected by the presence of BA. Shoots number and length were significantly achieved on MS medium contained 2.0 or 2.5 $\mathrm{mg} / \mathrm{l}$ of $\mathrm{BA}$ combined with $0.2 \mathrm{mg} / \mathrm{l}$ of NAA. In vitro rooting, shoots were rooted on MS basal solid medium contained either IBA singly or mixture of IBA and NAA. Shoots were rooted well on MS basal solid medium supplemented with $2.0 \mathrm{mg} / \mathrm{l}$ of IBA .Rooted shoots were planted in pots filled with peat moss and sand ( $1: 1) \mathrm{v} / \mathrm{v}$ mixture. Survival percentage for adapted plantlet were $90 \%$ after 4 weeks. The plantlets were transferred to polyethylene bags and replanted successfully under field conditions.

Keywords: Balanitaceae, Balanites aegyptiaca, in vitro propagation, heglig, desert date, growth regulators.

\section{INTRODUCTION}

Balanites aegyptiaca (L) Del, (Family: Balanitaceae) an evergreen tree is a multipurpose plant known for its many uses as fodder, charcoal, timber, fuel wood, antifeed (Von Myddell, 1984). It is widely distributed from Guinea through the Sahara into Egypt. It is encountered on clay soils under rainfall of $500 \mathrm{~mm}$.(Giffard, 1974).It is sporadically distributed on sandy soils under rainfall of $250 \mathrm{~mm}$. The species, which occur in arid zone, grows very slowly and has a slow fruit development. Balanites aegyptiaca (L) Del, is ecologically very flexible with excellent persistence. It is adaptable to a wide range of sites and climatic conditions (Von Myddell, 1984). Although the tree regenerates naturally by seed or after moderate coppice, the species is endangered because of the high rate of clearance, (El-Nour, et al., 1991). Micro-propagation on tree species offers a rapid means of producing Clonal planting stock for afforestation, woody biomass and conservation of elite germplasm (Bonga and Durzan, 1982). The tissue culture of forest trees has shown promise in obtaining regenerants and Clonal multiplication for domestication of wild populations, afforestation and improvement of economically important trees that have been cultivated for generations. Plant tissue culture is an alternative method of propagation (George and Sherrington, 1984) and is being used widely for the commercial propagation of a large number of plant species, including many medicinal plants (Rout et al., 2000). Since, many medicinal plant species are disappearing at an 
alarming rate due to rapid agricultural and urban development, uncontrolled deforestation and indiscriminate collection. (Fay, 1992), advanced biotechnological methods of culturing plant cells and tissues should provide new means of conserving and rapidly propagating valuable, rare, and endangered medicinal plants. Micro-propagation is also, a powerful tool for the quick production of genetically homogenous plants, it allows to obtaining a large number of plants from the very limited source available. In Egypt, Balanites aegyptiaca (L) Del. is known as Balah haraara; Igleeg; Ligleeg; Hel'eig and Hegeleeg, (Täckholm, 1974).It's considered an endangered plant, So the aim of this study was to assess the effect of growth regulators on in vitro shoot proliferation and in vitro rooting of Balanites aegyptiaca (L) Del. This paper describes the work carried out on in vitro propagation of Balanites aegyptiaca $(L)$ Del. as an important medicinal plant for the supply of raw materials for extraction of medicinally important compounds for the pharmaceutical industry

\section{MATERIALS AND METHODS}

\section{Plant Materials}

Young vigorous shoot tips of wild Balanites aegyptiaca (L) Del. were collected from Paris Oasis, Alwadi Algadeed, Egypt, 2004 and immediately transferred to the laboratory and used as the source of explants.

\section{Preparing Of Explants}

Shoot tips were excised with four leaves primordia. The explants were thoroughly washed under the running tap water for 30 minutes, then disinfected in $1 \%$ sodium hypochlorite $(20 \%$, v/v), clorox solution plus three drops of tween 20 for 15 minutes with periodical agitation, followed by rinsing three times with sterile distilled water under aseptic conditions.

\section{Culture Medium And Conditions}

MS basal solid medium, (Murashige and Skoog, 1962) was used for culture initiation and different micro-propagation stages. Medium was supplemented with $3 \%(\mathrm{w} / \mathrm{v})$ sucrose and gelled with $0.6 \%$ agar. The $\mathrm{pH}$ value of the medium was adjusted to 5.8 and the medium was sterilized by autoclaving at $15 \mathrm{lb} / \mathrm{IN} 2$ pressure and $121^{\circ} \mathrm{C}$ for 20 minutes. The cultures were incubated at $26 \pm 2{ }^{\circ} \mathrm{C}$ under $16 \mathrm{~h}$. photoperiod with cool white fluorescent lamp.

\section{Culture Initiation}

Shoot tips were prepared and cultured onto MS basal solid medium supplemented with $0.1,0.2,0.5$ and $1.0 \mathrm{mg} / \mathrm{l}$ of 6 - benzyl adenine (BA) combined with $0.1 \mathrm{mg} / \mathrm{l}$ of $\alpha$ - naphthalene acetic acid (NAA) as well as control. All treatments were incubated for 4 weeks and data were taken as survival \%, shoot growth as response percentage and length $(\mathrm{cm}$.).

\section{MULTIPLICATION OF SHOOTS}

The responding cultures were used for the multiplication trails (multiple shoots induction). Explants at least $1 \mathrm{~cm}$. long were transferred onto MS basal solid medium supplemented with $0.5,1.0,1.5,2.0$, and $3.0 \mathrm{mg} / \mathrm{l}$ of 6 benzyl adenine (BA) in combination with $0.2 \mathrm{mg} / \mathrm{l}$ of $\alpha$ - naphthalene acetic acid (NAA), the control treatment as well. All cultures incubated for 4 weeks, 
and data were recorded as shoots number per explants and shoot length (cm.).

In Vitro Rooting

For root induction, healthy micro-shoots $(1-2 \mathrm{~cm}$. long) were transferred into MS basal solid medium contained 1.0 and $2.0 \mathrm{mg} / \mathrm{l}$ of Indol 3butyric acid (IBA) alone or in combination with 1.0 and $2.0 \mathrm{mg} / \mathrm{l}$ of $\alpha$ naphthalene acetic acid (NAA),control as well. All cultured were incubated as mentioned prior. Data were taken after 6 weeks as root formation percentage $(\%)$, roots number / micro-shoot and root length $(\mathrm{cm}$.$) .$

\section{Hardening And Field Planting}

Healthy rooted plantlets generated in vitro were transferred to small pots containing sterile mixture of peat moss and sand $(1: 1 \mathrm{v} / \mathrm{v})$ and kept in incubation room for 4 weeks for first stage of hardening. They were later transferred to polyethylene bags containing the same mixture and kept in nursery for second stage of hardening. After 8 weeks of growth in the nursery, the plants were transferred to the field in the experimental station, Siwa Oasis, Matroh Governorate, Egypt.

\section{Data Analysis}

The experiment was repeated twice according to a completely randomized experimental design; 15 jars were used for each treatment. Analysis of variance was performed with model procedure (SPSS 8.0 statistical package) and mean comparison with Duncan's multiple range tests. Significance was recorded at $p \leq 0.05$.

\section{RESULTS AND DISCUSSION}

\section{Establishment Of Culture}

Among all the used treatments in Table (1), the explants in MS medium were healthy and grow vigorously. Shoot tip explants started to grow within 4 weeks. MS medium without any growth regulators failed to form any new micro-shoots as comparison to other treatments. Shoot survival and growth were affected by all treatments tested in Table (1) without significant differences. Addition of BA at level $0.5 \mathrm{mg} / \mathrm{l}$ combined with NAA in rate of 0.1 $\mathrm{mg} / \mathrm{l}$ increased the survival of explants till $100 \%$ and shoot elongated to 1.93 $\mathrm{cm}$. Medium supplemented with $0.5 \mathrm{mg} / \mathrm{l} \mathrm{BA}$ in combined with $0.1 \mathrm{mg} / \mathrm{l} \mathrm{NAA}$ was superior in terms of shoot length as well as shoot growth as response $(100 \%)$ in Figure (1).

Table (1): Effect of growth regulators on shoot survival \% and shoot length

(cm.) in vitro Balanites aegyptiaca after four weeks
\begin{tabular}{|c|c|c|c|c|c|}
\hline BA & NAA & No. of & Shoot Survival & \multicolumn{2}{c|}{$\begin{array}{c}\text { Shoot } \\
\text { Length(cm.) }\end{array}$} \\
mg/l & mg/l & Replicates & $(\%)$ & 0.86 d \\
\hline 0.0 & 0.0 & 15 & 86.66 a & $0.11 \quad$ cd \\
0.1 & 0.1 & 15 & 86.66 a & $1.33 \quad$ bc \\
0.2 & 0.1 & 15 & 93.33 a & $1.93 \quad$ a \\
0.5 & 0.1 & 15 & 100.00 a & $1.46 \quad$ b \\
1.0 & 0.1 & 15 & 93.33 a & 1.46 &
\end{tabular}

Different letters within columns indicate significant difference $(p \leq 0.05)$ 


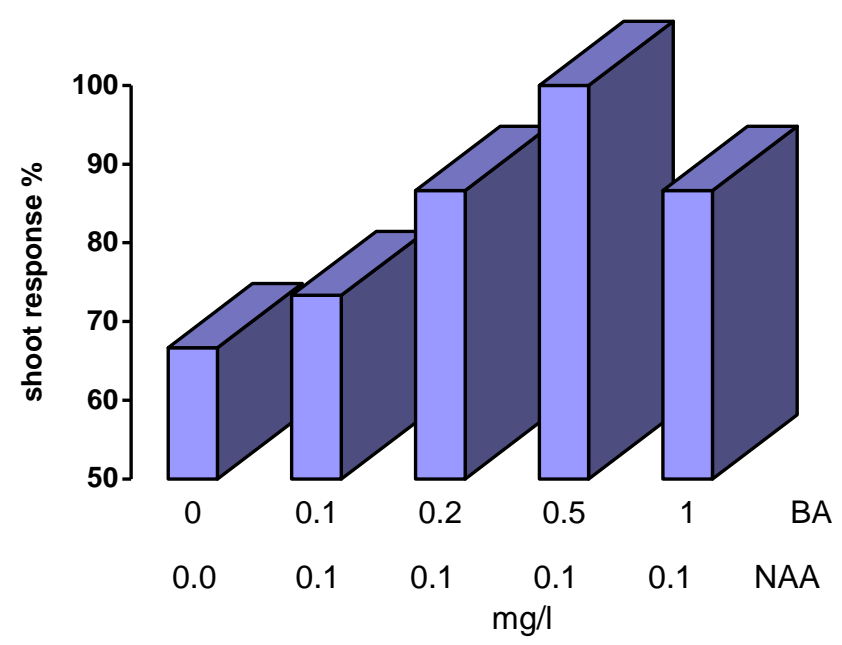

Figure (1): Effect of growth regulators on shoot response \% in vitro Balanites aegyptiaca after four weeks

\section{Multiplication Of Shoots}

In order to select the most suitable medium for multiplication, different combinations were tried and the results are given in Table (2).

Table (2): Effect of growth regulators on shoot growth and Proliferation in vitro of Balanites aegyptiaca after four weeks

\begin{tabular}{|c|c|c|c|c|c|}
\hline $\begin{array}{c}\mathrm{BA} \\
\mathrm{mq} / \mathrm{l}\end{array}$ & $\begin{array}{l}\text { NAA } \\
\mathrm{mq} / \mathrm{l}\end{array}$ & $\begin{array}{c}\text { No. of } \\
\text { Replicates }\end{array}$ & \multicolumn{3}{|c|}{ Shoots growth } \\
\hline & & & $\begin{array}{c}\text { No. of new micro } \\
\text { shoots /explant }\end{array}$ & \multicolumn{2}{|c|}{$\begin{array}{c}\text { Shoot } \\
\text { length }(\mathrm{cm} .)\end{array}$} \\
\hline 0.0 & 0.0 & 15 & 0.000 & 0.000 & C \\
\hline 0.5 & 0.2 & 15 & 0.466 & 0.816 & b \\
\hline 1.0 & 0.2 & 15 & 1.660 & 2.560 & $\mathbf{a}$ \\
\hline 1.5 & 0.2 & 15 & 3.800 & 2.840 & $\mathbf{a}$ \\
\hline 2.0 & 0.2 & 15 & 4.660 & 2.873 & $\mathbf{a}$ \\
\hline 2.5 & 0.2 & 15 & 4.533 & 2.626 & $\mathbf{a}$ \\
\hline 3.0 & 0.2 & 15 & 3.500 & 2.630 & $\mathbf{a}$ \\
\hline
\end{tabular}

Different letters within columns indicate significant difference ( $p \leq 0.05$ )

The results of this study show that, axillary bud explants from mature mother plants of $B$. eagyptiaca can be readily established in MS medium containing 2.0 or $2.5 \mathrm{mg} / \mathrm{l} \mathrm{BA}$ plus $0.2 \mathrm{mg} / \mathrm{l} \mathrm{NAA}$ to produce multiple shoots. Figure (2) shows the effect of growth regulators on shoots productivity. Increasing BA concentrations affected positively shoot number, and shoot length. Consequently, productivity was affected. BA in rate of $2.0 \mathrm{mg} / \mathrm{l}$ was the most effective among all treatments tested. The highest productivity value was achieved with shoots subcultured for one month on MS medium supplemented 
with $2.0 \mathrm{mg} / \mathrm{l} \mathrm{BA}$ plus $0.2 \mathrm{mg} / \mathrm{l} \mathrm{NAA}$, while From the results, it could be concluded that, shoot productivity are useful variables, since they combined the effect of the treatments on shoot number, length and nodes to give a general idea of the behavior in vitro shoots. Similar results have been reported by other workers, ( Bajaj,1986 ; Chalupa, 2002 ; Sudhersan and Hussain, 2003 and Gomes et al., 2003) using explants derived from woody plants .MS medium without any growth regulators enhanced shoot growth and elongation, while medium with BA enhanced axillary branching explants furthering multiple shoot development of nodes. This result agrees with the finding of Mansour et al., (2003) on B. eagyptiaca. Productivity $(\mathrm{mm})=$ shoot number per explant $\mathrm{x}$ shoot length (mm), (Perez Tornero et al.,2000)

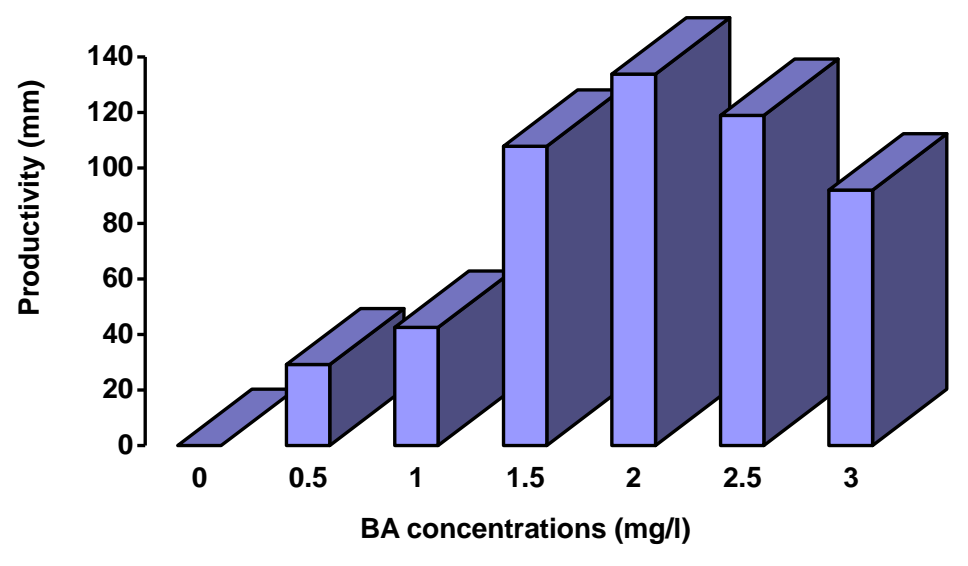

Figure (2): Effect of growth regulators on shoot productivity $(\mathrm{mm})$ in vitro of Balanites aegyptiaca after four weeks

\section{In Vitro Rooting}

Roots began to emerge on day 8 and by day 12 were clearly visible . Rooting percentages determined on day 28 and the result presented in Table 3 and Figure (3).

Table (3): Effect of auxins as IBA and NAA on rooting stage in vitro of Balanites aegyptiaca after 4 weeks.

\begin{tabular}{|c|c|c|c|cc|cc|}
\hline $\begin{array}{c}\text { IBA } \\
\text { mg/l }\end{array}$ & $\begin{array}{c}\text { NAA } \\
\text { mg/l }\end{array}$ & $\begin{array}{c}\text { No. of } \\
\text { Replicates }\end{array}$ & \multicolumn{2}{|c|}{$\begin{array}{c}\text { Root } \\
\text { formation } \%\end{array}$} & \multicolumn{2}{|c|}{$\begin{array}{c}\text { Root No. / } \\
\text { explant }\end{array}$} & $\begin{array}{c}\text { Root length } \\
\text { (cm.) }\end{array}$ \\
\hline 0.0 & 0.0 & 15 & 13.33 c & 0.200 & c & 0.500 & c \\
1.0 & 0.0 & 15 & 53.33 b & 0.933 & b & 2.820 & b \\
2.0 & 0.0 & 15 & 86.66 a & 2.133 & a & 5.066 a \\
1.0 & 1.0 & 15 & 80.00 a & 1.866 & a & 4.433 a \\
2.0 & 2.0 & 15 & 86.66 a & 2.266 & a & $3.866 \quad$ ab \\
\hline
\end{tabular}

Different letters within columns indicate significant difference ( $p \leq 0.05$ ) 


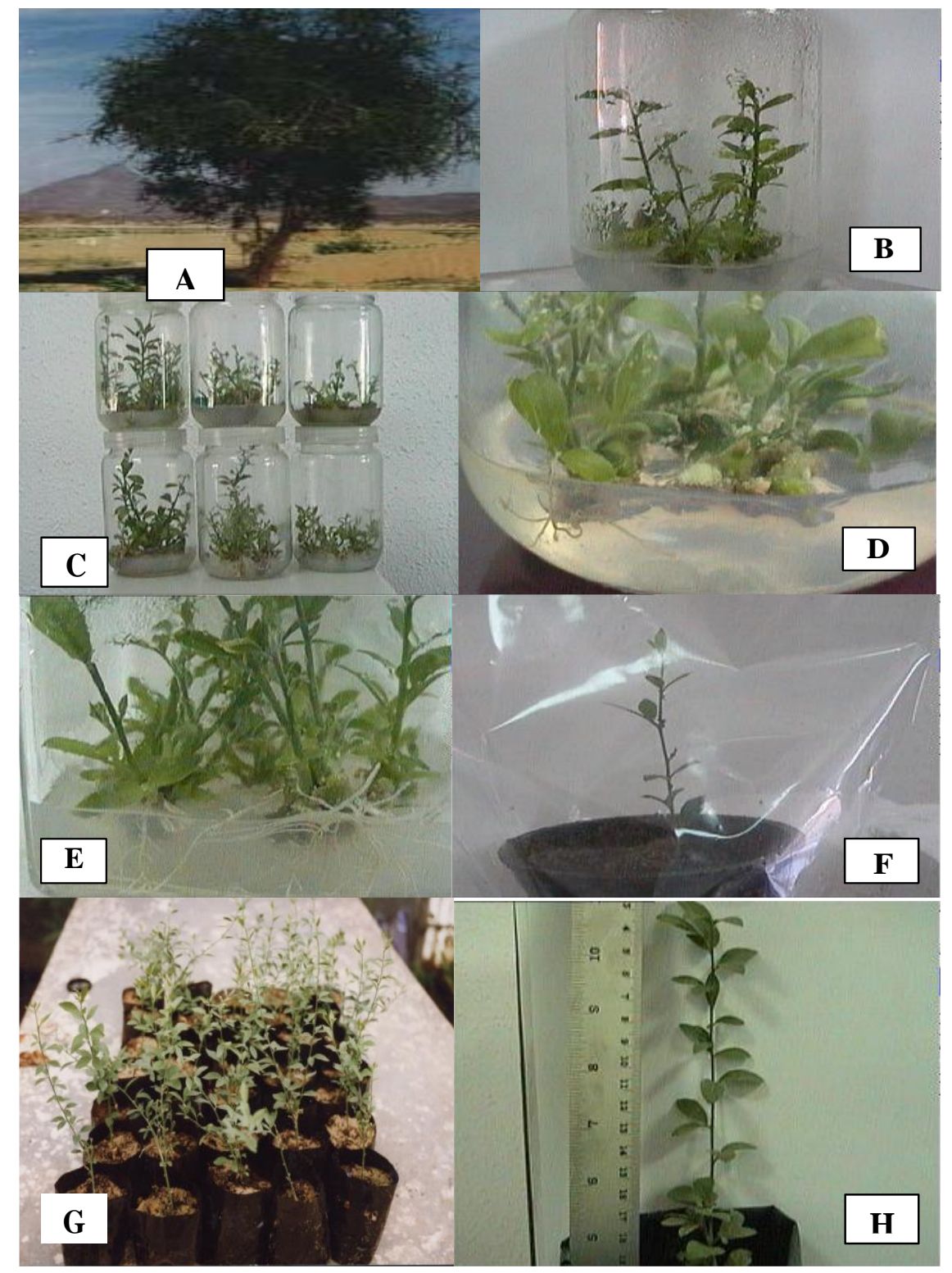

Figure (3): In vitro micro propagation of. A) wild Balanites eagyptiaca (L) Del tree, B) Induction of axillary bud growth in vitro, C) multiple shoots in different treatments, D\&E) in vitro rooting, F) ex vitro hardening, in soil G) hardening of plantlets, in nursery, $\mathrm{H}$ ) plantlet ready to transfer into the field. 
A satisfactory rooting percentage was achieved only by using IBA or in combination with NAA after 4 weeks. At $2.0 \mathrm{mg} / \mathrm{L}$ of IBA $86 \%$ of the 15 micro shoots involved in this treatment developed roots with an average of 2.133 roots / shoot and $5.066 \mathrm{~cm}$ root length. The same rooting percentage was obtained by the combination of $2.0 \mathrm{mg} / \mathrm{L}$ of IBA and $2.0 \mathrm{mg} / \mathrm{L}$ of NAA, but root length was shorter $(3.866 \mathrm{~cm})$. Rooting formation percentage and growth was appeared the lowest value in medium without growth regulators as comparison to the other treatments .Both the concentration and nature of the auxins used markedly influenced root formation, number and length per shoot. high root numbers (fig.2) were induced by medium IBA combined with NAA concentration. MS medium without auxins, the roots failed to emerge high positive result, the rooting was $13.33 \%$ after 4 wks, this results as contrary to the results of Mansour et al.,(2003) on B. aegyptiaca, may be due to the effect of growth regulators accumulation in the pervious stage. According to El Nour et al., (1991), the IBA auxin did not improve rooting significantly which is contrary to our results. From the results, it could be concluded that, rooting percentage, root number and root length / explant obtained in medium containing 1.0 and $2.0 \mathrm{mg} / \mathrm{L}$ of IBA either individual or combined with 1.0 plus $2.0 \mathrm{mg} / \mathrm{l}$ of NAA, showed no statistical significant differences compared to that with $1.0 \mathrm{mg} / \mathrm{l}$, although root length had decreased .In this concern, this result agrees with Llerente and Apostolo, (1998) also, confirmed with Mansour et al.,(2003), They state that, rooting of shoots in vitro was achieved on MS medium containing indolebutyric acid (IBA). Tyagi and Prakash, (2004) found that, no rooting was observed on MS medium devoid of auxin in Jojoba shoots. All succeeded plantlets have not any callus on base of stem. This result is considered high positive as comparison to obovious result, whereas the highest value was $48 \%$ (Mansour et al.,2003), the difference may be due to callus formation. Ajithumar and Seeni, (1998) confirmed this result , they stated that, most of the roots differentiated from the calli did not have a vascular connection with the stem and establishment of the plants after hardening was poor. Rooted shoots were transferred to peat moss: sand mixture and acclimatized in the greenhouse under high humidity conditions and transferred to soil. The percentage survival of plantlets was $90 \%$. The plants did not show any morphological variation.

\section{Conclusion}

Induction of multiple shoots was achieved in the axillary buds of the shoot tip explants on MS basal medium supplemented with $0.5 \mathrm{mg} / \mathrm{l} \mathrm{BA}$ plus $0.1 \mathrm{mg} / \mathrm{l} \mathrm{NAA}$. An increase in the number of shoots per explant (4.6) was observed when the shoots were sub-cultured on MS medium supplemented with 2.0 or $2.5 \mathrm{mg} / \mathrm{l} \mathrm{BA}$ plus $0.2 \mathrm{mg} / \mathrm{l} \mathrm{NAA}$ over the other BA and NAA combination tested. The optimum rooting response was obtained on auxins enriched medium. In vitro generated plantlet could be esablished with $90 \%$ success on initial hardening in the incubation room. These plantlets could be established with 90\% success under the nursery condition (Figure 3). Hardening plants have been planted in the field, esablished with $100 \%$ success. Therefore, in vitro propagation of $B$. aegyptiaca will be of immense 
importance as it allows obtaining a large number of plants from the very limited source available. Also, these results could be utilized for mass production to get active materials and also would help in conserving the germplasm and commercial cultivation of this economically important medicinal plant.

\section{REFERENCES}

Ajithumar D.and Seeni S, (1998): Rapid clonal multiplication throug in vitro axillary shoot proliferation of Aegle marmelos (L.) Corr., a medicinal tree. Plant Cell Reports, $17: 422-426$.

Bajaj Y.P.S.,(1986) : Biotechnology in Agriculture and Forestry, Trees 1, Spinger - verlag, berlin, pp 515.

Bonga M. and Durzan D.J., (1982): Tissue culture in forestry , Martinus Nijhoff, the Hague, Boston, London, 387 p.(C.F Mansour N.; Ismail D. and Yaye Kene G., (2003). African Journal Biotechnology, Vol. 2 : (11), pp 421-424,

Chalupa V.( 2002):In vitro propagation of mature trees of Sorbus aucuparia $L$. and field performance of micropropagated trees. Journal of forest science, 48 (12): 529-535.

El Nour M.; El khalifa, Massimo K. and El Hassan B.,(1991): Preliminary study on seed pre-germination treatment and vegetative propagation of Balanites eagyptiaca (L.) Del. Groupe d'Etude de l'arbre, Paris, France, pp 413-415.(Abst.)

Fay M.F. (1992):Conservation of rare and endangered plants using in vitro methods. In Vitro Cell. Dev. Biol.-Plant. $28: 1$ - 4

George, E. F. and Sherrington P. D., (1984): In Plant propagation by tissue culture, Exegetics Ltd., Eversley, England, pp. 39-71.

Giffard P.L., (1974): L'arbre dans le paysage senegalais. Sylviculture en zone tropicale seche. Centre Tech . Forest, Tropical. Dakar, p 431, (Abst. C.F, http://www.bioline.org.br/request) .

Gomes G. A.; Paiva R.; Paiva P. D.and De Santiago E. J., (2003): Plant regeneration from callus cultures of Maclura tinctoria, an endangered woody species. In Vitro Cell Dev. Biol. plant. $39(5,6)$ : 293 - 295.

Llerente B., and Apostolo N. H., (1998): Effect of different growth regulators on propagation of jojoba. New Zeal. J. Crop. Hort. Sci. 26: 55-62.

Mansour N.; Ismail D. and Yaye Kene G.,(2003): In vitro multiplication of the semi arid forest tree, Balanites aegyptiaca (L) Del. African Journal Biotechnology, Vol. 2 : (11), pp 421-424.

Murashige, T. and F. Skoog. (1962): A revised medium for rapid growth and bio-assays with tobacco tissue cultures. Physiol.Plant.15:473 - 497.

Perez - Tornero; J.M. Lopez and Burgos L. (2000) : Effect of basal media and growth regulators on the in vitro propagation of Apricot (Prunus arminica L.) c.v. Canino. Journal of Horticultural Science \& Biotechnology, 75 (3) : $283-286$.

Rout G.R.; Samantaray S. and Das P. (2000): In vitro manipulation and propagation of medicinal plants. Biotechnol. Advances.18 : 91-120. 
Sudhersan C. and Hussain J., (2003) : In vitro Clonal propagation of a multiplication trees, Ziziphus spina- Christ (L) Desf. Turk J.Bot., 27 167-171.

Täckholm V.,(1974): Student's flora of Egypt,2nd Ed. Published by Cairo University, Printed by Cooperative Printing Company, Beirut.

Tyagi R. K. and Prakash S., (2004): Genotype and sex specific protocols for in vitro micropropagation and medium term conservation of Jojoba. Biological plantrum, 48 (1) : $19-23$.

Von Myddell H.J.,(1984): Arbres et arbustes du shahel: lerns caracteristiques et leurs utilizations. Eschborn: GTZ, 531 p. (C.F Mansour N.; Ismail D. and Yaye Kene G., (2003). African Journal Biotechnology, Vol. 2 : (11), pp 421-424, 